Article

\title{
Do Temporary Creative Clusters Promote Innovation in an Emerging Economy?-A Case Study of the Beijing Design Week
}

\author{
Huasheng Zhu ${ }^{1,2, *}$, Kebi Chen ${ }^{2}$ and Yunlong Lian ${ }^{2}$ \\ 1 The State Key Laboratory of Earth Surface Processes and Resource Ecology, Beijing Normal University, \\ Beijing 100875, China \\ 2 Faculty of Geographical Science, Beijing Normal University, Beijing 100875, China; \\ chenkebi@mail.bnu.edu.cn (K.C.); 201621170021@mail.bnu.edu.cn (Y.L.) \\ * Correspondence: zhuhs@bnu.edu.cn; Tel.: +86-10-58800193
}

Received: 5 February 2018; Accepted: 9 March 2018; Published: 11 March 2018

\begin{abstract}
Extant research indicates that temporary clusters, such as trade fairs and exhibitions, play a significant role in knowledge dissemination and innovation by creating global buzz, so they are beneficial to building global pipelines. However, these findings are mainly based on the experiences in the manufacturing sectors of developed countries. This paper, however, chooses Beijing as a case to examine whether or not international exhibitions in creative industries contribute to innovation in emerging economies. Based on questionnaire surveys and semi-structured interviews conducted in 2015-2016, this paper uses a structural equation model (SEM), with three latent variables related to global buzz, global pipelines, and information acquisition, to identify the internal patterns of exhibition innovation. The results indicate that there exists innovation generated from temporary clusters in knowledge-intensive sectors as well as emerging economies. Global buzz and global pipelines construct a favorable interaction ecology. However, global buzz plays a greater role than global pipelines. This insight should help organizers improve creative exhibitions in terms of innovation and provide a deeper understanding of the relationships between innovation, global buzz, and global pipelines in temporary clusters.
\end{abstract}

Keywords: global buzz; global pipelines; temporary clusters; innovation; exhibitions; Beijing

\section{Introduction}

Nowadays, the importance of distance knowledge, as opposed to local knowledge, is being emphasized in the literature on industrial clusters [1-3]. It is believed that without external linkages, local knowledge transferred among local firms tends to be homogeneous, and local development tends to be exposed to the risk of being 'locked' in the original path or the dilemma of 'path dependence' [4]. Path dependence highlights the influence of specific conditions on the evolution of regional economies, such as preexisting resources, competences, skills, and experiences [5]. Too much path dependence leads to lock-in, so it has negative consequences on economic clusters, which in turn leads to economic stagnation or even decline [6]. Extra-regional knowledge linkages frequently support the development of new paths [7]. Therefore, to sustain endogenous growth through innovation, it is necessary for local firms and other economic actors to build up cross-regional cooperation and seek external knowledge resources [8].

Cross-regional interactions, which usually rely on periodic, temporary, and face-to-face communications [2], such as 'pipelines' [9], 'listening posts' [10], 'crowdsourcing' [11], trade fairs [12], and other professional gatherings [13], are becoming as important as local interactions [2]. Recently, economic geographers have extended their academic interests to the role of exhibitions in knowledge 
creation and innovation [14], and revealed the selection and mutation processes of knowledge actors in exhibition environments [15]. Compared to local, stable interactions within specialized clusters, interactions at exhibitions can help actors to increase accessibility to new knowledge and information through the external connections provided by such temporary space-time aggregations [12]. Maskell, Bathelt, and Malmberg (2006) [12] refer to exhibitions as 'temporary clusters' in that they have similar functions to industrial clusters in achieving interactions and knowledge exchange. Actors who participate in such events are automatically exposed to 'global buzz' [12], which means a specific communication and information pattern, or professional communication and information ecology, developed by participants such as exhibitors, visitors, experts, and observers participating in international exhibitions [16,17]. Within this ecology, market information, professional knowledge, as well as news, or gossips are circulated as a result of the temporary get-together of a diverse set of participants from all over the world. These actors build their relationships and networks [18] through on-site observations, comparisons, and face-to-face interactions [19], which facilitates the establishment of 'trans-local pipelines' or 'global pipelines' [12,19]. Meanwhile, the high cost of interactions brought by the external links and the uncertainty of distant interactions also decreases [12]. Hence, it is fairly certain that 'global buzz' and 'global pipelines' can be generated by a temporary cluster, and they can stimulate and accelerate the processes of knowledge creation and diffusion, forming a complementary relationship with permanent clusters [12]. In addition, periodically conducted exhibitions can be viewed as 'cyclical clusters' [18]. These exhibitions and their overlapping functional spaces can continuously reproduce, reenact, and renew spaces for businesses or innovation over time.

However, extant literature has not yet refined sufficiently the dimensions of 'global buzz', 'global pipelines,' and further information acquisition in temporary clusters. Moreover, the findings that have been made have come mainly from the experiences of developed countries; very few have come from the experiences of emerging economies. As for emerging economies, such as Egypt, India, and Indonesia, exhibitions are beneficial in opening up international markets [20], and thereby stimulating local economic growth [21]. However, their sustainable development increasingly requires innovation capabilities [22], while only a few scholars find burgeoning international exhibitions in emerging economies, such as China [15]. These can also bring about knowledge generation and relationship building as is the case in developed countries. This point deserves more case studies and further investigation. Equally importantly, current discussions are overly focused on the traditional manufacturing field; only a few studies turn to creative and knowledge-intensive sectors (for example, case studies on creative festivals as creators of temporary knowledge networks [23,24]). Compared with manufacturing sectors, the burgeoning creative industries are supported by higher levels of skill and talent, and are more dependent on temporary coalitions of diverse and often mobile workers [25], with a focus on individual talent creativity [26]. Creativity has become a source of competitive advantage in such industries and people there are involved in the manipulation of ideas rather than materials [27]. Thus, one wonders whether or not temporary creative clusters may perform better in terms of knowledge innovation rather than market expansion. Furthermore, creative industries highlight the combination of culture, art, science and technology, and commercial value rather than mere technical breakthroughs [26]. Further, interactions with knowledge-intense institutions such as universities [28] and high-quality consumers with highly uncertain taste [25] are important for knowledge creation. These characteristics suggest that the global buzz and global pipelines in temporary creative clusters could be facilitated by various actors in different geographical and industrial contexts-Bathelt points out that knowledge creation and diffusion processes embedded in the exhibitions are diverse in different countries or different industries [29]. Clearly, there is a need for more complementary studies focusing on emerging economies as well as creative and knowledge-intensive industries. To fill these gaps, this paper includes two dimensions to reveal the internal mechanisms of innovation in temporary clusters: (1) to enrich the case studies of temporary clusters and explore the interaction characteristics in different geographical and industrial contexts, and (2) to refine the relationships among 'global buzz', 'global pipelines,' and further information acquisition. 
The remainder of this paper is structured as follows. Section 2 reviews relevant literature. Section 3 introduces the methodology, including targeting case, data collection, and modeling. Section 4 analyzes the results, gives further explanations based on on-site interviews, and then engages in some discussion. Some conclusions are drawn in the final section.

\section{Buzz, Pipelines, and Innovation at Temporary Clusters}

Temporary clusters have many forms, e.g., conventions, congresses, trade fairs, conferences, and exhibitions $[12,19]$. This section focuses mainly on interactional exhibitions, and examines the notions of global buzz and global pipelines in this context.

\subsection{Global Buzz at Temporary Clusters}

In the literature on industrial clusters, 'buzz' refers to the information and communication ecology created spontaneously by face-to-face contacts, co-presence, and co-location of people and firms within the same industry and place or region [30]. Initially, buzz was viewed as a local phenomenon and as a thick web of information, knowledge, and inspiration that circulates among the actors within an industrial cluster [9]. However, if firms rely exclusively on internal markets and knowledge circulating through such local buzz, the potential of economic growth cannot be unfolded in the long term [9]. Bathelt, et al. (2002) [30] suggested that there exists a 'global pipeline' to 'pump' something new to local buzz. The 'global pipeline' refers to the channel used in distant interactions [31], which we will detail later in part 2.2. However, even though one assumes the existence of global pipelines, there is still a shortage of attention to buzz generating on a global scale. Actually, within the space of a temporary cluster, such as an international exhibition, there usually is a temporal context where social interaction and intensified knowledge exchange take place [32], in which some specific communications and information patterns are developed by exhibitors, visitors, experts, observers, and other participants from all over the world. Bathelt et al. (2004) termed this 'global buzz' [30], which is a specific knowledge ecology that reduces the uncertainties present in the market and technology development [33]. It is believed that global buzz, which is rooted in the specific context of temporary clusters, is a third type [32] or a transition between local buzz and global pipelines to promote unique processes of knowledge dissemination and creation through interactive learning and learning by observation [34].

Bathelt and Schuldt (2010) point out the constitutive components of global buzz, including global co-presence, intensive face-to-face interaction, different possibilities for observation, multiplex meetings and relationships, as well as intersecting interpretative communities with overlapping visions [17]. The co-presence at and around the exhibition is a necessary precondition [17]. Actors from all over the world attend trade fairs with different roles and expectations. Their 'get-together' brings about a specific atmosphere, which is helpful for learning and knowledge diffusion [17]. Various actors, e.g., exhibitors, visitors, customers, suppliers, and professionals, congregate in the same space-time and bring considerable heterogeneous information and distant knowledge [12]. This increases the opportunities for participants to discover something novel [17], and the peers, institutions, or information at the exhibition enlighten participants with inspiration at the scene or after the activities [35]. This plays an important role in information updating [30], knowledge spillover [19], creation of new ideas [36], as well as innovation [37].

Global buzz relies on observations or intensive face-to-face interaction-within a specific institutional setting, participants acquire knowledge by observing, monitoring or face-to-face communications [17]. The open space with high accessibility of exhibitions allows the actors to perceive this interactive environment through their senses of sight, touch, smell, hearing, and even taste, in the process, gaining access to some intensive or tacit knowledge [35]. The free access to such information and communication ecology is a natural consequence of just 'being there' [38,39]. In the communication and observation processes during these events, verbal and non-verbal cues, visual stimuli, as well as feelings and emotions are omnipresent and act as the central elements in the resulting knowledge flows [34]. These unanticipated processes expose actors automatically to 
booths, roadshows, reports, gossip, opinions, recommendations, and interpretations about production information, technology, professional knowledge, market trends, novel ideas, and so on.

Focused communities, consisting of diverse mixtures of practice and epistemic communities, can also be an important component of global buzz [17]. Indeed, the boundaries of temporary clusters can be defined in advance, that is, organizers are able to select proper exhibitors and visitors to take part in the events [18]. Formal and informal guidelines help target the right market segments and exclude others. Moreover, some knowledge is encouraged to be released while certain undesired knowledge flows are hindered [40]. All this guarantees to some degree, a common knowledge basis or cognitive proximity, and contributes to mutual understanding [30] as well as efficient transfers of information and knowledge [17]. It helps establish 'focused communities' with overlapping and complementary knowledge bases, and creates a high-quality professional milieu [17]. What is more, various other activities are also conducted in the exhibition, including the evening events, leisure shows, salons, and so on. These scheduled or accidental meeting opportunities in the exhibition hall or around the hall (such as in a hallway or the lobby [19]) can help the actors obtain some direct or credible feedback and gain access to new information and knowledge pools [17,41].

\subsection{Relationships and Potential Pipelines between Actors at Exhibitions}

Exhibitions are also considered as 'relational events' [42], which means that exhibitions aggregate different actors from different regions, and provide opportunities for setting up mutual relationships. There are generally three kinds of potential industrial linkages, namely, horizontal, vertical, and lateral relationships [43]. Longitudinal relationships exist between the exhibitors, (potential) customers, suppliers, and other actors, and they are very common in commercial trade fairs. Horizontal relationships often depend on professional awareness or common interest, and mainly exist between competitors within similar fields. Lateral relationships are the linkages between and within members of non-related industries. As these relationships are significant for information acquisition [44], they are further beneficial to knowledge cross-fertilization and innovation [43].

However, apart from those existing before the exhibitions, the relationships developed at exhibitions often seem temporal, but they also facilitate the generation of global temporary networks [45]. Thus, the international exhibitions become central nodes in the global political economy [19]. However, these temporal linkages do not stay strong without continuous maintenance, such as through the continuous management of repetition, work, and regular attention [18].

The relationships between different actors from different regions or even countries facilitate the building up of 'global pipelines', which some scholars term [12,30] as information and knowledge transfer. Unlike global buzz at exhibitions, global pipelines actually are formal, structured, and thoroughly planned linkages [30,46] and require conscious efforts and substantial investments $[13,33]$. Based on such pipelines, actors could have opportunities to interact with distant partners [9,31] and then get access to distant markets and knowledge pools [12].

In previous literature, pipelines established or maintained at exhibitions perform two roles. Firstly, they make new linkages of partners and information, or maintain and even strengthen the existing relationships. As for making new linkages, though it is a tricky and costly process to identify, select, approach, and interact with new partners [12], exhibitions could be helpful in scouting potential partners so as to build global pipelines with nearly little risk and extra cost $[12,19,30]$. Due to the milieu of exhibitions, actors can search for the information purposefully, make intentional observations, or communicate with exhibitors of interest to them [35], and encounter 'a stimulating environment' which is different from that of their daily activities [47]. Furthermore, the actors obtain knowledge through the global buzz in the exhibitions and identify suitable partners to make initial promising contact, and then develop durable inter-firm pipelines consciously for ideas, technology, production and/or marketing [19]. In return, global pipelines provide access to novel and non-redundant information that can create further spillover and spur innovation [48]. As for the maintenance of relationships, in terms of certain exhibitions held regularly, which are termed as a phenomenon of 'cyclical clusters' 
in global circuits [18], peer firms or personnel have opportunities to get together periodically [17]. Existing relationships are also maintained or even intensified at the exhibitions $[19,47]$.

We have clarified above the role of global pipelines available at an exhibition to identify potential partners as well as to maintain the existing relationships with distant partners. Actually, these global pipelines refer to trans-local linkages, and establishing pipelines with distant partners is a process of building linkages. At the exhibition, these pipelines may be performed as consciously built relationships or networks. However, linkages established on the spot at an exhibition are often temporal, so follow-up maintenance or reinforcement then becomes indispensable in the future.

\subsection{Extension to Buzz-Pipeline Model: The Analytical Framework of This Research}

Bathelt, et al. (2002) proposed a 'buzz-pipeline' model to describe the process of knowledge creation, emphasizing the role of local buzz and global pipelines, as well as their mutual effects [30]. As far as knowledge creation in industrial clusters is concerned, co-location of people and firms within the same industry and place brings about local information and knowledge sharing, which generates the 'buzz'; while global pipelines 'pump' new information and distant knowledge into the cluster, and further facilitate the buzz. The two seem to be mutually reinforcing [30]. As Bathelt (2007) points out, both local buzz and global pipelines have only limited effects if they remain as separated spheres [9], while the combination of both concepts, namely, the buzz-pipeline model provides a new perspective for the dynamics of local knowledge creation and innovation [13,30]. However, some scholars have argued further that buzz has little value while pipelines play a leading role under some specific circumstances [49]. It is possible that the buzz-pipeline model shows mixed results in different cases [48].

Now, as mentioned above, such as exhibitions, global buzz and global pipelines are considered to be two main ways of getting access to distant information and knowledge via temporary clusters. Global buzz takes place when participants are just 'being' at exhibitions [30]. This refers to an unintentional process similar to knowledge spillover, and the participants on the scene are far-ranging and unpredictable. By contrast, global pipelines focus on directional and systematic information, building channels of communication and cooperation between local milieu and distant actors [30]. One may therefore wonder whether global buzz and global pipelines play different roles in knowledge innovation in temporary clusters as buzz-pipeline model shows in different cases.

Figure 1 is structured based on the ideas presented in Sections 2.1-2.3 to describe the conceptual framework of factors to describe the creation of innovation in temporary clusters, as a consequence of global buzz and global pipelines. In addition, the purposes behind the actors participating in exhibitions are varied. For exhibitors, their intentions are divided into 'behavior-based' or 'selling-based' (In a behavior-based control system, the process is addressed, rather than simply the outcome(s). 'Behavior' here means what people do (i.e., the tasks they expend effort on while working); the selling-based system measures the output, including all activities related to on-site sales and sales after the events.) [50]. For visitors, the motivations vary in terms of buying, meeting, stocking knowledge, seeking inspiration, and updating professional skills, etc. [47]. These different purposes may affect the actors' behaviors, performances, and other achievements at the exhibition. Furthermore, some scholars have said that revisiting the same exhibition every year is the preference of most firms [18], and can be helpful in maintaining previously established relationships or become a favorable basis for the stimulation of new relationships [17]. However, others have observed that nearly half of the exhibitors would not participate in the same exhibition again [51]. That means whether or not it is the participants' first time to participate in such an exhibition may influence their achievements. As a result, the present authors use these two factors, purposes and revisit as control variables, and set up a framework of innovation in exhibitions as Figure 1 shows. 


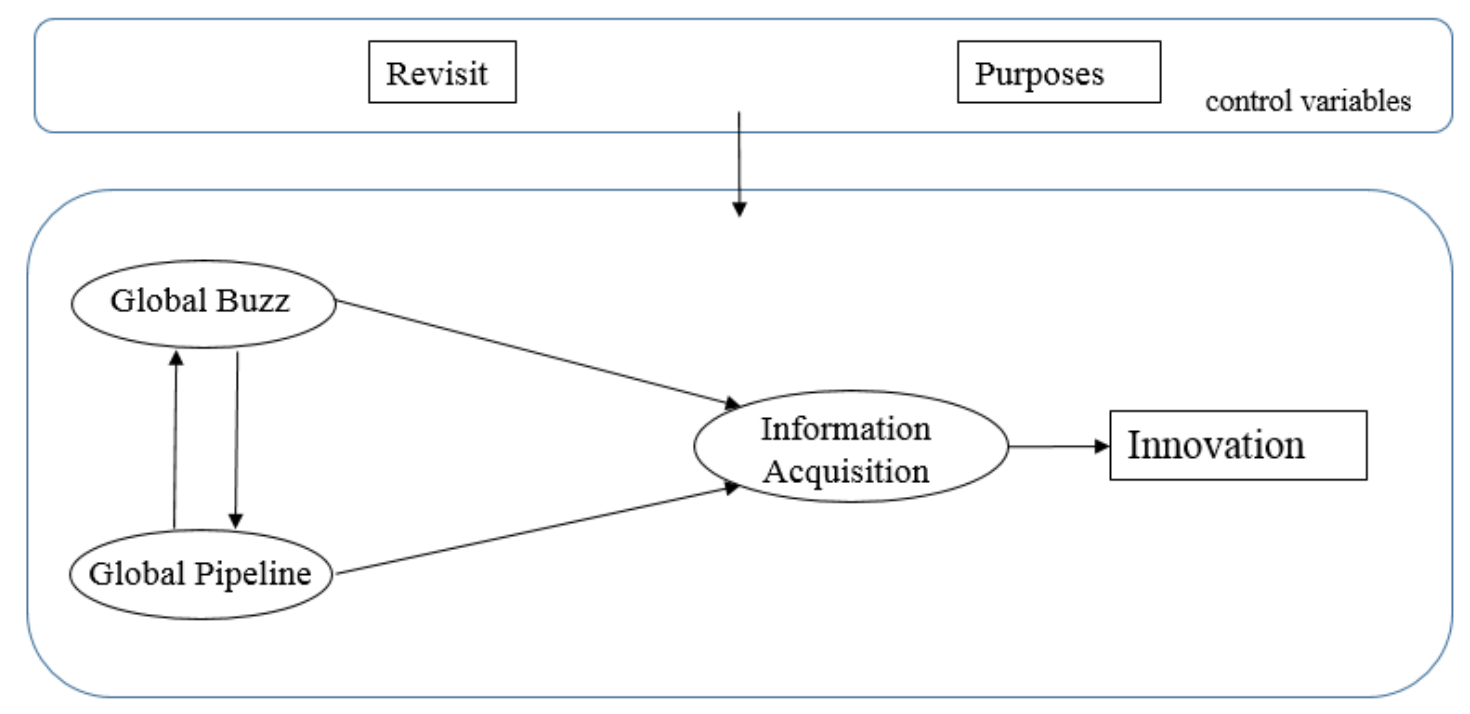

Figure 1. Framework of the effects of exhibitions on innovation.

It should be noted that, in this framework, innovation does not refer to quantifiable outcomes such as patents or visible performances at the scene of the exhibition, but rather refers to the possibility for creation. It highlights the processes of learning and interactions. In this article, we use self-assessment to measure the possibility of future innovation. The path connecting information acquisition (IA) to innovation (I) only stands as a possibility to influence future innovation. As extant literature shows, innovation is an interactive learning process with social and territorial embeddedness [52]. It not only means the creation of absolutely brand-new knowledge, but also refers to improving understanding and achieving new developments for existing things, such as renewing and changing knowledge, merging new elements, or adding new forms into existing knowledge, putting forward new problem-solving, and so on [53]. It is a process of searching and discovering, with imitation, adoption, or the development of new products, new processes, or new organizational models [54]. Therefore, such innovation emphasizes the interactions among the actors, as well as the exchange and collision of information at exhibitions.

\section{Methodology}

\subsection{Target Case}

The authors choose Beijing Design Week, an international exhibition as the case. Beijing was designated by United Nations Educational, Scientific, and Cultural Organization (UNESCO) in 2012 as the capital of design in the international Creative Cities Network. Beijing Design Week is one of the ten initiative members of the World Design Week (WDW), and has been held eight times since 2009. It is the first design week in China to be invited to join in the WDW, owing to its characteristics of being comprehensive, authoritative, and international, and a high reputation in China's creative industries [55].

Beijing Design Week is co-sponsored by the central government People's Republic of China and Beijing Municipal Government. The chief organizers are Beijing Gehua Cultural Development Group (a large-scale state-owned cultural operation organization in Beijing [56]) and Beijing Industrial Design Center (BIDC, an independent legal entity of the institutions, directly under the Beijing Municipal Science \& Technology Commission, aiming to promote design value and design development). It also attracts design parks, design agencies, universities, and other institutions to co-host the event every year.

Beijing Design Week is a comprehensive and periodical event. Since 2009, it has been successfully held for eight years, in Beijing and in recent years, even spread to Tianjin and Hebei. It lasts from late 
September to early October each year and includes the National Day Holiday from 1-7 October. As the largest design week in Asia, Beijing Design Week attracts more than 2000 participants including designers, institutional representatives and academic experts every year, as well as more than 100 registered media and 5 million visitors [57]. Beijing Design Week 2017 boasts 44 venues and 10 main content sections with the activities in the field of cultural and creative industry and design-related activities reaching nearly one thousand. The event has so far attracted over 10,000 designers and design agency representatives coming from more than 20 countries, more than 8 million visitors at the scene, and more than 50 million online visitors, driving a total of more than 3 billion yuan in cultural tourism and other consumption of various design activities [58].

Beijing Design Week is the only A-type international creative design activity in Mainland China that is recognized worldwide [59]. It consists of a series of large-scale exhibitions and other activities, e.g., opening ceremony, design awards, 'guest cities', 'design tours', professional forums, trade fairs, etc., and some activities are adjusted according to the annual plan [60]. The 'design tour' is a platform for participants to display, communicate, experience, and interact with exhibitors from different places. The fields involved are also various, e.g., architectural design, industrial design, and fashion design, handicrafts design and so on. Although the venues are spread all over the city, the main design activities of Beijing Design Week concentrate on some specific areas like China Millennium Monument, 798 \& 751 Art Zone, and the Dashilan Area. Each sub-venue has a relatively unique topic field, e.g., industrial design and art design in the $798 \& 751$ art areas and architectural/urban design in the White Pagoda Temple area.

\subsection{Field Surveys and Data Collection}

The authors conducted their field surveys for data collection during 2015-2016. The surveys were focused on professional visitors rather than exhibitors for the following considerations. First, individual actors are carriers of knowledge [7], as in the Creative Industries Mapping Document [61] promulgated by the department of DCMS in the UK in 1998, creative industries have their origin in individual creativity. Creative firms have characteristics of miniaturization, flattening, and individualization. Apart from the firms, the actors who participate in knowledge creation are often extensively creative individuals (such as artists [23], designers, and visitors), and they play an important role in creative exhibitions. Furthermore, in creative cities, talents are the basic drivers of growth that can be designated as the 'creative class' [62]. In spite of emphasizing the harvest and behaviors of firms as exhibitors [18,33,63], previous research also noted the exhibition effects on individuals like visitors. Apart from purchasing behaviors (or potential purchasing behaviors), visitors at exhibitions also perform ongoing searching, which is concerned more with information than with purchase. Thus, they harvest unexpected knowledge, inspiration, reassurance, and relationships, or just realize a sense of satisfaction by taking part in 'an institutionalized activity' in the ritual dimension [47]. They constitute the most important partners with whom exhibitors interact [19], which implies that similar harvest from interactions will also happen to visitors.

The authors carried out their questionnaire surveys in 2015. The questionnaires aimed to collect basic information on the respondents and measure the innovation they were 'harvesting' from the activity, as well as to find the factors that influenced the innovation. The exercise consisted of two parts, the first part was the scale survey of behaviors and achievements at the exhibition, and the second involved the identification of the basic characteristics of the responders. Screening of 'professional visitors' was based on a self-assessment by the respondents-before starting the questionnaire survey, we asked the respondents if they were working in or studying in fields related to creative industries. If yes, the survey would continue.

The questionnaire survey was conducted at the scene of the exhibition. On average, it took about 15-20 min to complete the questionnaire. The authors waited for the completion of each questionnaire, and then collected it. Although the activities lasted from the end of September to the beginning of October, our questionnaire survey was conducted mainly in October because the main visitor flows 
appear at the beginning of October since it coincides with the statutory holiday in China. To ensure the randomness and extensive coverage of the sample, the questionnaire survey was conducted at multiple locations during Beijing Design Week 2015, mainly in the areas of Dashilan, 798 \& 751 Art District, Community of the White Pagoda Temple, and China Millennium Monument. China Millennium Monument was the main venue of the Beijing Design Week where the opening ceremony was held, while $798 \& 751$ Art District and Community of the White Pagoda Temple attracted many professional visitors in professional contexts and Dashilan attracted a large volume of people from different areas.

Although the questionnaires were useful in measuring quantitative relationships, they could not reveal mechanisms behind the data. Therefore, we conducted in-depth interviews (Table 1) to determine the details of the interviewees' behaviors during the exhibition, with the question 'How does the innovation appear in the creative temporary cluster?' Fourteen interviews were conducted (numbered V1-V14) in 2015 Beijing Design Week, since the respondents who had answered the questionnaires were willing to communicate with us on the spot, which lasted about $30 \mathrm{~min}$. Considering the hysteretic effects of innovation as well as the establishment of pipelines, we selected another six respondents (numbered V15-V20, who completed the questionnaire survey at the exhibition in October 2015) to pay a return visit with the help of the contact information they entered in the questionnaires. The revisits were made about two months after the Beijing Design Week according to the practices of Hansen K [50], and because the previous research had shown that the effects of the exhibition may last for several months [18]. The revisit is also worked as a supplement to our investigation as it answered some remaining puzzles and lasted for about one hour.

Besides, we continued the interviews in 2016 Beijing Design Week, mainly to verify the identified framework of innovation effect based on the questionnaires as well as the interviews numbered from V1-V20 in 2015. Therefore, another 17 interviews were conducted (numbered V21-V37, lasting about $30 \mathrm{~min}$ ) and these interviewees were randomly selected at the exhibition with the same premise as the 'professional visitors' test.

Table 1. Stages, aims and designs of the semi-structured interview.

\begin{tabular}{|c|c|c|}
\hline Stage & Aims & Main Questions \\
\hline I: October 2015 & $\begin{array}{l}\text { Determine the details of the interviewees' } \\
\text { behaviors during the exhibition, answering the } \\
\text { question of 'How does the innovation appear } \\
\text { in the creative temporary cluster?' }\end{array}$ & $\begin{array}{l}\text { (1) Basic information; (2) harvests from the activities, and } \\
\text { the ways to gain them; (3) the innovation effects and the } \\
\text { way to gain them; (4) the behaviors at the exhibition, } \\
\text { such as the way to communicate and interact. }\end{array}$ \\
\hline II: December 2015 & $\begin{array}{l}\text { Consider the hysteretic effects of innovation as } \\
\text { well as the establishment of pipelines, and } \\
\text { work as supplement of investigation, } \\
\text { answering some remaining puzzles of Stage I }\end{array}$ & $\begin{array}{l}\text { (1) Basic information; (2) harvests from the activities, and } \\
\text { the ways to gain them; (3) the innovation effects (at the } \\
\text { spot or after the events) and the way to gain them; } \\
\text { (4) the behaviors at the exhibition, such as the way to } \\
\text { communication and interaction; (5) the way to establish } \\
\text { relationships; (6) the way to absorb and transform the } \\
\text { knowledge gained at the exhibition. }\end{array}$ \\
\hline III: October 2016 & Verify the identified framework of innovation & $\begin{array}{l}\text { (1) Do the various actors, various activities, interactions, } \\
\text { and observations exist at the exhibition? And how did } \\
\text { they affect the information collection and further } \\
\text { innovation? (2) Is it true that the exhibition is beneficial } \\
\text { for the establishment or the maintenance of relationships? } \\
\text { How did it happen? (3) What are the innovation effects } \\
\text { and how do we gain them. }\end{array}$ \\
\hline
\end{tabular}

In the end, we collected 425 questionnaires during the survey, with 365 of them being valid in the first part of the questionnaire (but may have had some information missing in the second part of the questionnaire), with a validity rate of $85.88 \%$. The basic information on valid samples is shown in Table 2. The professional visitors included the staff of cultural companies or design institutes, students of art or design, independent designers, free-lance designers, in-house designers, etc. Thirty seven interviews were conducted in total besides the questionnaire surveys. Appendix A Table A1 shows the occupational areas of interviewees; it covers a variety of design areas like industrial design, arts, urban design, and so on. 
Table 2. Basic characteristics and distribution of samples.

\begin{tabular}{|c|c|c|c|c|}
\hline Characteristics & & Classification & Number & Percentage \\
\hline \multirow{13}{*}{ Basic Characteristics } & \multirow{7}{*}{ Age } & $\leq 20$ & 60 & $16.44 \%$ \\
\hline & & $21-30$ & 151 & $41.37 \%$ \\
\hline & & $31-40$ & 68 & $18.63 \%$ \\
\hline & & $41-50$ & 30 & $8.22 \%$ \\
\hline & & $51-60$ & 14 & $3.84 \%$ \\
\hline & & $>60$ & 6 & $1.64 \%$ \\
\hline & & No response & 36 & $9.86 \%$ \\
\hline & \multirow{6}{*}{ Education } & Junior high school and below & 3 & $0.82 \%$ \\
\hline & & Senior high school & 16 & $4.38 \%$ \\
\hline & & Professional high school, technical secondary school or junior college & 210 & $57.53 \%$ \\
\hline & & Master's & 82 & $22.47 \%$ \\
\hline & & PhD and above & 10 & $2.74 \%$ \\
\hline & & No response & 44 & $12.05 \%$ \\
\hline \multirow{16}{*}{ Participations } & \multirow{3}{*}{ Origin } & Beijing & 299 & $81.92 \%$ \\
\hline & & Other cities in China & 61 & $16.71 \%$ \\
\hline & & Other countries and regions & 5 & $1.37 \%$ \\
\hline & \multirow{10}{*}{ Sectors } & Art \& Cultural Services & 22 & $6.03 \%$ \\
\hline & & News \& Publication & 9 & $2.47 \%$ \\
\hline & & Radio, Television, and Film & 13 & $3.56 \%$ \\
\hline & & Software \& Information Technology & 30 & $8.22 \%$ \\
\hline & & Advertising \& Exhibition & 10 & $2.74 \%$ \\
\hline & & Arts/Crafts Production and Sales & 34 & $9.32 \%$ \\
\hline & & Design & 141 & $38.63 \%$ \\
\hline & & Cultural and Recreational Services & 12 & $3.29 \%$ \\
\hline & & Production and Sales of Stationery and other ancillary services & 5 & $1.37 \%$ \\
\hline & & Other sectors & 89 & $24.38 \%$ \\
\hline & \multirow{3}{*}{ Invitation } & Invited by the organizer & 114 & $31.23 \%$ \\
\hline & & Not invited by the organizers but obtained information from other sources and actively participated & 247 & $67.67 \%$ \\
\hline & & No response & 4 & $1.10 \%$ \\
\hline
\end{tabular}




\subsection{Modeling}

We utilized a structural equation model (SEM), also known as a latent variable model (LVM) [64], to identify the paths along which innovation probably happens at creative exhibitions. SEM makes it possible to test the relationships between dominant variables, latent variables, disturbance variables or error variables, and then obtain the direct, indirect, or overall effects in the model (The direct effect in the structural equation model is the direct effect of the causal variable to the result variable. The indirect effect refers to the indirect effect on the result variable through some mediating variables. The overall effect is the sum of the direct effect and the indirect effect.). As for the complicated and progressive paths as well as the latent variables (global buzz, global pipelines, and information acquisition) mentioned in Section 2, SEM can be effectively used due to its advantage of estimating potential variables as well as detecting complex path structures. For example, Hansen K (2004) has linked its complex performance to information-gathering, relationship-building, image-building, motivation activities, and sales-related activities at trade shows [50].

\subsubsection{Variables Selection}

Table 3 details the variables selected and the associated measurements. Global buzz, global pipelines, and information acquisition are latent variables and were measured by three observable variables each using the five-point Likert scale with point ' 5 ' as 'totally agree' and point ' 1 ' as 'strongly disagree'. The two control variables were dichotomous variables, measured as ' 0 ' or ' 1 '. Both scale and dichotomous variables are allowed in SEM; their skewness and kurtosis (shown in Table 4) are fit for SEM in view of their normality [51], and the sample size satisfies the basic requirements of SEM as well as the maximum likelihood (ML) method used in parameter estimation [65].

\subsubsection{Measured Model, Reliability and Validity Analysis}

Three measure models (three latent variables) were constructed using nine measured variables in total, with three of each respectively. The results of exploratory factor analysis (EFA) among nine variables in SPSS 21 led to the same classification of these three constructs. The Total Variance Explained for these measurement variables was $78.756 \%$, with $\mathrm{KMO}=0.795>0.7$. The Barlett Sphere test showed that $p=0.000<0.001$. Cronbach' $\alpha$ was used to test the reliability of each measured model with all the Cronbach' $\alpha$ of latent variables being higher than 0.7 , thus pointing to a good reliability of the measured model (Table 5) [66].The convergence validity of the scales was tested by the average variance extracted (AVE). It was calculated using the results. A confirmatory factor analysis (CFA) was conducted in AMOS 21. The resulting AVE values ranged from 0.550 to 0.736 , all above the minimum of 0.5 suggesting acceptable reliabilities of the constructs [67]. They were all higher than the squares of the correlations between any pairs of different constructs, thus confirming their discriminant validity (Table 5) $[66,68]$. 
Table 3. Indexes and measurement variables of the structural equation model.

\begin{tabular}{|c|c|c|c|c|}
\hline Latent Variables & $\begin{array}{l}\text { Measured } \\
\text { Variables }\end{array}$ & Description of Meaning/Measurable Concept & Measurable Question & Quantitative Criteria \\
\hline Innovation & I & $\begin{array}{l}\text { The possibility of further innovation through } \\
\text { the exhibition [12] }\end{array}$ & $\begin{array}{l}\text { Participating in this event has had a great impact } \\
\text { on my innovation or creation of new ideas }\end{array}$ & \multirow{10}{*}{$\begin{array}{l}\text { Higher points for higher agreement, } 5 \text { stands } \\
\text { for 'totally agree' and } 1 \text { for 'strongly disagree }\end{array}$} \\
\hline \multirow{3}{*}{ Global buzz } & GB1 & $\begin{array}{l}\text { Co-presence of various and heterogeneous } \\
\text { actors }[17,30]\end{array}$ & $\begin{array}{l}\text { There are various and heterogeneous actors } \\
\text { participating in this exhibition }\end{array}$ & \\
\hline & GB2 & Interaction and observation $[17,19,34]$ & $\begin{array}{l}\text { I carried out some observations and interactions at } \\
\text { this exhibition }\end{array}$ & \\
\hline & GB3 & Temporary communities $[17,23]$ & $\begin{array}{l}\text { I can get access to a range of activities at } \\
\text { this exhibition }\end{array}$ & \\
\hline \multirow{3}{*}{ Global pipeline } & GP1 & $\begin{array}{l}\text { Identification of potential partners } \\
{[12,18,19,40,47]}\end{array}$ & $\begin{array}{l}\text { I have already identified some exhibitors or other } \\
\text { actors who are suitable to be my potential partners }\end{array}$ & \\
\hline & GP2 & Strengthen or maintain relationship $[18,19,47]$ & $\begin{array}{l}\text { I have already met (intended to meet) some old } \\
\text { friends/partners at this exhibition }\end{array}$ & \\
\hline & GP3 & $\begin{array}{l}\text { Willingness to develop a long-lasting } \\
\text { relation }[18,19,40,47]\end{array}$ & $\begin{array}{l}\text { I intend to contact some interested actors } \\
\text { encountered at this exhibition in the future }\end{array}$ & \\
\hline \multirow{3}{*}{ Information acquisition } & IA1 & $\begin{array}{l}\text { latest information on new products or } \\
\text { technology }[12,18,47]\end{array}$ & $\begin{array}{l}\text { I obtained the latest information on new products } \\
\text { or technology at this exhibition }\end{array}$ & \\
\hline & IA2 & Professional knowledge $[4,17,47]$ & $\begin{array}{l}\text { I obtained some professional knowledge at } \\
\text { this exhibition }\end{array}$ & \\
\hline & IA3 & New ideas and inspiration $[18,19,23,47]$ & $\begin{array}{l}\text { I gained many enlightening ideas for inspiration at } \\
\text { this exhibition }\end{array}$ & \\
\hline \multicolumn{5}{|l|}{ Control Variables } \\
\hline Revisit & $\mathrm{R}$ & $\begin{array}{l}\text { Whether to participate in regularly or } \\
\text { periodically }[17,18]\end{array}$ & $\begin{array}{l}\text { Have you ever participated in Beijing Design Week } \\
\text { at least one time? }\end{array}$ & $\begin{array}{l}\text { 1-Yes, I have participated in it in the past; } \\
0 \text {-No, this is my first time to participate in } \\
\text { this event. }\end{array}$ \\
\hline Purposes & $\mathrm{P}$ & The motivations behind participation $[47,50]$ & $\begin{array}{l}\text { Do you have any purposes for attending, such as } \\
\text { information or networking? }\end{array}$ & $\begin{array}{l}\text { 1—Yes, I do; } \\
0 \text {-No, I have no special purpose. }\end{array}$ \\
\hline
\end{tabular}


Table 4. The statistical characteristics of the sample.

\begin{tabular}{llllll}
\hline Variables & Factor Load $\boldsymbol{\lambda i}$ & Mean & Standard Deviation & Skewness & Kurtosis \\
\hline I & - & 3.76 & 1.028 & -0.495 & -0.388 \\
GB1 & 0.826 & 3.71 & 0.951 & -0.566 & 0.000 \\
GB2 & 0.905 & 3.70 & 0.988 & -0.615 & -0.035 \\
GB3 & 0.817 & 3.53 & 0.976 & -0.221 & -0.445 \\
GP1 & 0.906 & 2.97 & 1.190 & -0.45 & 0.845 \\
GP2 & 0.979 & 3.01 & 1.230 & -0.088 & -0.902 \\
GP3 & 0.655 & 3.09 & 1.212 & -0.170 & -0.899 \\
IA1 & 0.759 & 3.60 & 0.988 & -0.496 & -0.166 \\
IA2 & 0.706 & 3.28 & 1.053 & -0.124 & -0.654 \\
IA3 & 0.758 & 3.77 & 1.060 & -0.608 & -0.262 \\
R & - & 0.469 & 0.500 & - & - \\
P & - & 0.948 & 0.222 & - & - \\
\hline
\end{tabular}

Table 5. Results of the validity and reliability test.

\begin{tabular}{cccccc}
\hline $\begin{array}{c}\text { Correlations (the Square } \\
\text { of the Correlations) }\end{array}$ & Global Buzz & Global Pipeline & $\begin{array}{c}\text { Information } \\
\text { Acquisition }\end{array}$ & Cronbach' $\alpha$ & AVE \\
\hline Global buzz & $1.000(1.000)$ & & & 0.886 & 0.723 \\
Global pipeline & $0.221(0.049)$ & $1.000(1.000)$ & & 0.883 & 0.736 \\
Information acquisition & $0.645(0.416)$ & $0.398(0.158)$ & $1.000(1.000)$ & 0.787 & 0.550 \\
\hline
\end{tabular}

\subsubsection{The Construction of Structural Model and Fit Test}

A structural model was developed to identify the statistically significant relationships among the key constructs of the exhibition innovation. Since there existed two opposite directions between global buzz and global pipeline, a non-recursive model had to be used. The model selected consisted of two control variables (purpose and revisit) and three explanatory variables, namely, global buzz (GB), global pipelines (GP), and information acquisition (IA) for innovation (I). In the AMOS 21, the maximum likelihood method (ML) was used to test the hypotheses. After suitable modification, the model led to optimal results: $p=0.179>0.05$, which suggested that the sample had fitted the model fully. The Chi-square value/degree of freedom (NC) equaled $1.204<2$, with Root Mean Square Error Approximation $($ RMSEA) $=0.024<0.05$, and with the rest of the model fit indexes also being well-fitted (Table 6).

Table 6. Model fit summary.

\begin{tabular}{ccc}
\hline Fitness Indicators & Fit Reference & Result of Our Model \\
Chi-square & - & 46.940 \\
Degree of freedom (DF) & - & 39 \\
Probability level (P) & $>0.05$ & 0.179 \\
\hline & Absolute fitness index & 0.980 \\
Goodness of Fit Indes (GFI) & $>0.9$ & 0.028 \\
Root Mean Square Residual (RMR) & $<0.05$ & 0.024 \\
\hline Root Mean Square Error Approximation (RMSEA) & $<0.05$ & 0.959 \\
\hline Value added fitness index & 0.979 \\
\hline Adjusted Goodness of Fit Index (AGFI) & $>0.9$ & 0.996 \\
Normative Fit Index (NFI) & $>0.9$ & 0.965 \\
Comparative Fit Index (CFI) & $>0.9$ & 0.996 \\
Relative Fit Index (RFI) & $>0.9$ & 0.994 \\
Incremental Fit Index (IFI) & $>0.9$ & 0.9 \\
Tucker-Lewis Index (TLI) & & \\
\hline
\end{tabular}


Table 6. Cont.

\begin{tabular}{ccc}
\hline Fitness Indicators & Fit Reference & Result of Our Model \\
\hline & Concise fitness index & \\
\hline PCFI & $>0.50$ & 0.589 \\
PNFI & $>0.50$ & 0.579 \\
NC (Chi-square/DF) & $1<\mathrm{NC}<3$ & 1.204 \\
\hline
\end{tabular}

Note: PCFI $=$ PRATIO $\times$ CFI, PNFI $=$ PRATIO $\times$ NFI, and PRATIO stands for the ratio between the DF of Independence model and the DF of Default model.

\section{Results and Discussion}

\subsection{Information Acquisition and Further Innovation at the Beijing Design Week}

Figure 2 shows the descriptive statistics results of the measured variables, which represent the existence of global buzz, global pipeline, information acquisition, and innovation at the exhibition. Information acquisition was manifested in several aspects considering the average value. New ideas and inspiration (IA3) was the most important one, which peaked at 3.77 of 5 . Latest information for new products or technology (IA1) was the second, with the value 3.60. Professional knowledge (IA2) was relatively unimportant but had an average value of 3.28. Furthermore, possibilities for innovation (I) was also notable, with a value of 3.76 .

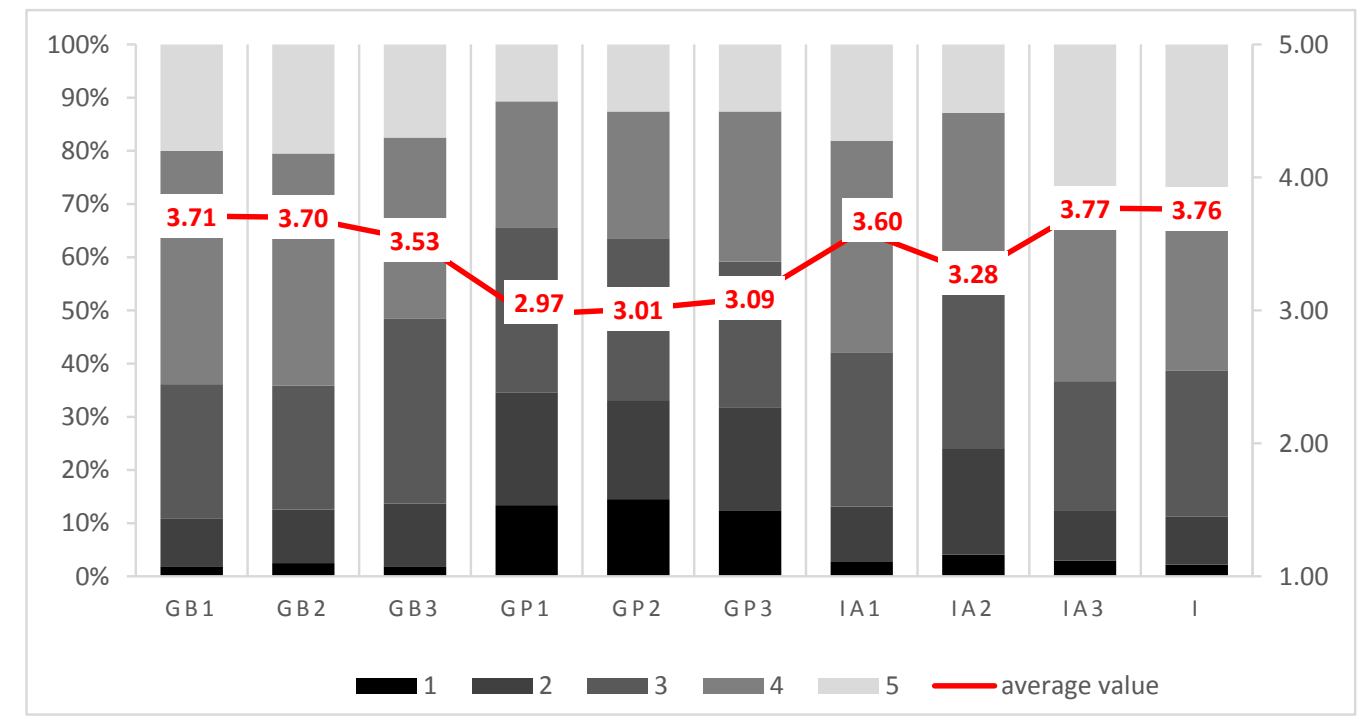

Figure 2. Frequency and percentage of measurement variables. Notes: (1) Data from the questionnaire survey; (2) higher points for better quality/ higher agreement, 5 stands for very good/ totally agree, 3 for neutrality and 1 for very bad/strongly disagree.

Several interviewees confirmed these conclusions, e.g., 'It's pretty fresh! I like it (V25)', 'It gives me inspiration for my creation (V26)', 'Something at the exhibition is very novel, and how fun it is! (V30)', 'This exhibition is an incentive mechanism for both designers and non-designers, showing a possibility in future $(V 1)^{\prime}$. It became clear that Beijing Design Week is a knowledge-intensive event, and is beneficial to information gathering and further innovation. However, how does such information acquisition and further innovation actually happen? In the next section, we will try to find some answers.

\subsection{Effects between Factors and Pathways of Innovation at Temporary Creative Clusters}

Figure 3 shows the normalized coefficients of the structural equation model. Table 7 shows the effects between factors. Three factors concerning innovation were revealed, namely global 
buzz (with a total effect equaling 0.471 on innovation), global pipeline (with a total effect equaling 0.276 on innovation), and information acquisition (with a total effect equaling 0.761 on innovation), thus suggesting that two paths to innovation are available.

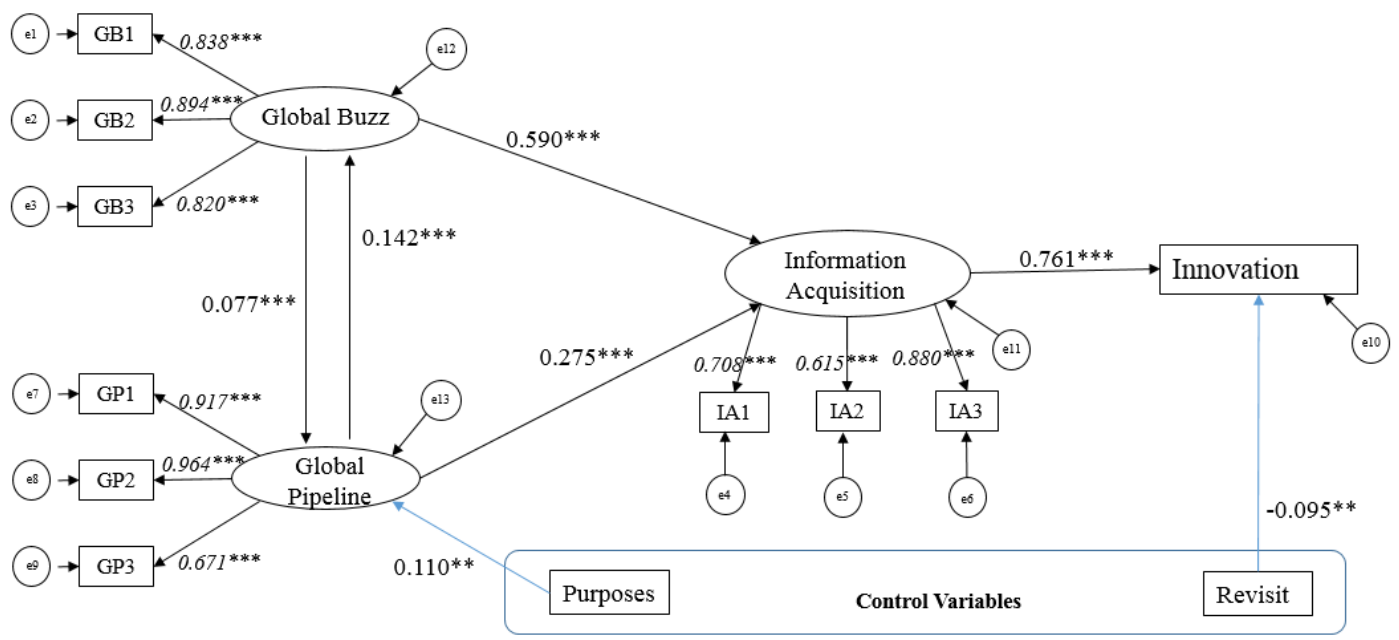

Figure 3. Optimal results from the innovation SEM for Beijing Design Week. Notes: (1) All the coefficients shown in the graph are standardized coefficients; $(2)^{* * *}$ represents a significance under 0.001 , and ${ }^{* *}$ stands for a significance between 0.01 and 0.05 .

In the first path from the global pipeline, through the global buzz, information acquisition to innovation, global pipelines affect global buzz $(\beta=0.142)$, global buzz has a further direct, positive, and significant effect on information acquisition $(\beta=0.590)$, followed by a direct, positive, and significant effect from information acquisition to innovation $(\beta=0.761)$. In the second path from global buzz, through global pipeline, information acquisition to innovation, global pipeline acts as an intervening variable between global buzz and information acquisition, global buzz facilitates the formation of global pipelines $(\beta=0.077)$, and global pipeline is further beneficial to information acquisition $(\beta=0.275)$. The two control variables show insignificant influence, only 'purpose' has a significant effect on global pipeline $(\beta=0.110, p=0.027)$, and 'revisit' has a significantly negative effect on innovation ( $\beta=-0.095, p=0.016)$. In summary, global buzz and global pipeline stimulate each other and both promote information acquisition. Further, information acquisition increases the possibility of innovation. In the following subsection, we will discuss the mechanisms of these paths in greater detail, based on both the model results and our field interviews.

Table 7. Direct/indirect/total effect of the innovation SEM for Beijing Design Week.

\begin{tabular}{|c|c|c|c|c|c|}
\hline Variables & Effects & $\begin{array}{c}\text { GB: Global } \\
\text { Buzz }\end{array}$ & $\begin{array}{l}\text { GP: Global } \\
\text { Pipeline }\end{array}$ & $\begin{array}{c}\text { IA: Information } \\
\text { Acquisition }\end{array}$ & I: Innovation \\
\hline \multirow{3}{*}{ GB: Global buzz } & Total Effects & 0.011 & 0.078 & 0.618 & 0.471 \\
\hline & Direct Effects & - & 0.077 & 0.590 & - \\
\hline & Indirect Effects & 0.011 & 0.001 & 0.028 & 0.471 \\
\hline \multirow{3}{*}{ GP: Global pipeline } & Total Effects & 0.143 & 0.011 & 0.363 & 0.276 \\
\hline & Direct Effects & 0.142 & - & 0.275 & - \\
\hline & Indirect Effects & 0.002 & 0.011 & 0.088 & 0.276 \\
\hline \multirow{3}{*}{$\begin{array}{l}\text { IA: Information } \\
\text { Acquisition }\end{array}$} & Total Effects & - & - & - & 0.761 \\
\hline & Direct Effects & - & - & - & 0.761 \\
\hline & Indirect Effects & - & - & - & - \\
\hline
\end{tabular}




\subsubsection{Global Buzz and Information Acquisition}

As the results of SEM show, global buzz plays the most significant role in information acquisition and further innovation. From the perspective of the participants, Beijing Design Week holds an idea of cross-sector design, and connects them to various institutions and actors from various design-related fields, including the fields of industrial design, urban planning, art design, film media, and so on. Thus, it attracts different participants from different design sectors, of which some are difficult to be connected on other occasions, especially for budding designers and new startups or famous enterprises. On aggregating these participants in a specific space-time context, various kinds of updating information seem to be flowing at the exhibition, such as the idea of design, the tendency of technology, the potentially increasing demands and so on. Without specific investments, actors who are 'being' in such space benefit from such 'global buzz': 'It (Beijing Design Week) involves a wide range of information, in fact, I just come here to 'meet', if I happen to meet something, it will be interesting $(V 26)^{\prime}$. As for the cross-sector characteristics of creative industries, the experience from other fields brings about some inspiration: ' . . some that seem to be irrelevant fashionable presentation techniques at the exhibition, like the video design shows, are also useful in my advertising design, and give me much inspiration (V6).' Furthermore, immersive experience and face-to-face communication should not to be ignored at the Beijing Design Week, for it is beneficial for getting access to tacit knowledge. As V31 mentioned in the survey, 'I can see these creative works with my own eyes at the exhibition. For example, the yard where we are, is well done with perfect craftsmanship. The construction and the entire material, as well as the design of the entire space, are wonderful enough, even the corners seem quite exquisite. I can see them and touch them. These are too detailed, so time consuming to find on the Internet while I am immersed in daily routines (V31)'. V35 believes that, with these activities, actors may not be able to immediately comprehend when they see something new, but 'consciously or unconsciously, it may inspire them in the future'.

\subsubsection{Global Pipelines and Information Acquisition}

Global pipelines play a role in social networking and sharing specific information among designated friends. As V10 said, 'I come here to make friends, I think the participants who come here have similar interests. At the exhibition, we will chat with each other, and if we find we are on the same wavelength, we are likely to continue to contact... For example, I made a new friend at the last Beijing Design Week ... we added Wechat to each other. Until now, we have continued to share something interesting, such as fashion design in another exhibition ... Usually, an enjoyable discussion follows (V10).'

Apart from making new friends and meeting old friends at the exhibition, it also brings some effective communication. For example, V11 is a designer and said to us, 'I will go to every exhibit area, where I have friends as exhibitors. I visit them, and then I will know their work better. Beijing Design Week has given me a chance to come together with my old friends; it is similar to a party (V11)'.

The establishment of these pipelines based on the actors' conscious efforts as well as the exhibition context. Participants search consciously for the things and information they are interested in at the exhibition, aiming to build some specific pipelines and gain some effective information directly. For example, V24 skimmed the entire schedule to look for interesting lecture topics on the Internet, and chose the proper day to visit the event: 'I came today because I know there will be a lecture on intelligent Internet plus hardware today. I'm very interested in it, and I knew several engineering designers, who I really appreciate, will come. I hope to get acquainted with them, and share my work and ideas with them, maybe we will get to know each other better and continue to communicate and even formally cooperate because of this activity. It is supposed to broaden my vision on frontier technologies and ideas, and it is probably beneficial for me to find some partners (V24)'. Sometimes, a new project can also develop through Beijing Design Week, with the purpose of furthering knowledge creation. Beijing Design Week is a venue for exhibitors like V16 who works on projects partnering with peer firms. Apart from that, Beijing Design Week is also an avenue for knowledge-intense events such as projects with universities or research institution. For example, Beijing Design Week (2015) provided a platform for collaboration of the Architectural Association School of Architecture (UK) and Tsinghua University, and an AAVS Beijing project was 
initiated to participate in the research of neighborhood revival and urban design: 'I am a student from Tsinghua University. We participated in the study of the revival of White Pagoda Temple Area, a historic and cultural neighborhood here ... Beijing Design Week brings us a good project proposition as well as a perfect group to cooperate with ... and we can also apply for a long-term research (V4)'.

In summary, we found that some potential pipelines were established at the exhibition, including linkages with friends, peers, suppliers, institutions and industry associations, universities as well as customers. These are beneficial for actors in collecting specific information. Some of these were already established links, but others are new, albeit still temporary and call for further identification and maintenance to determine if a longer cooperation is expected.

4.2.3. Interaction between Global Buzz and Global Pipeline, and Their Effect on Information Acquisition

A 'global buzz-global pipeline' mechanism occurs at the exhibition, with the combined effects of both global buzz and global pipelines on information acquisition. First, global buzz provides an interactive communicational ecology, which increases the trust among actors and decreases the cost of building global pipelines. For example, through face-to-face communication or observation practices at the exhibition, V16 was able to select proper potential partners, 'I received dozens of business cards, while the remaining is always only one or two actors that fitted my firm well ... On-site interactions brought us a sense of security because of the trust based on face-to-face communication, and it also decreased the cost of building new relationships'. Meanwhile, through existing global pipelines, something new may also be sent out to intensify the global buzz. For example, owing to the high reputation of Beijing Design Week, some internal activities like a periodical forum among specific acquaintances were conducted, which could be regarded as 'global pipelines'. Ordinary participants are not allowed to enter such activities, but they can also get something through the buzz at the scene. 'A forum about lacquer culture was held during this event, while it was only opened to specific lacquer craftsmen and I was not entitled to attend ... but it doesn't matter, when our participants are curious about the work and aggregate in front of the booth, the exhibitors are willing to share ideas with us. He said some ideas are latest enough from the internal forum in the events that he just participated (V9)'.

\subsubsection{The Comparative Importance of Global Buzz to Global Pipelines}

According to the model results, both global buzz and global pipelines positively promote information acquisition and innovation, while the impact of global buzz on information acquisition (total effect $=0.618$, direct effect $=0.590)$ is greater than that of global pipelines (total effect $=0.363$, direct effect $=0.275$ ).

The probable reason for this finding may be related to the organizational design of the Beijing Design Week. Some arrangements provide participants with little facilitation for the establishment of global pipelines. According to the interviews, few in-house designers of exhibitors attended the exhibition, and some core designers of famous firms (as exhibitors) are often absent from the booth as they are busy at work in their firms. So there was little opportunity for participants to have face-to-face talks with these creative staff. It was apparent that, without effective communications, the intention to establish a further pipeline for knowledge innovation decreases. In addition, some activities or events, such as high-level professional forums, are only open to small groups of specific exhibitors or participants. Though some information in such close forums can spread through global buzz as we mentioned above, in-depth interactions and further relations are difficult for ordinary participants, 'Those events may be more effective for deep communications and more beneficial for the establishment of relationships, but we ordinary participants cannot get access to them (V16)'.

\section{Conclusions}

Literature points out that as temporary clusters, exhibitions create a kind of 'global buzz', and provide opportunities for participants to build 'global pipelines' between different places, which 
facilitate knowledge diffusion and innovation. Much attention has been paid to the communication and information ecology of temporary clusters in the context of the developed countries and the manufacturing world. This paper, however, has focused on creative industries and knowledge-intense fields in an emerging economy. Its biggest contribution is the recommendation to further investigate in a different industrial and geographical context.

The case of the Beijing Design Week in this paper has confirmed that, as temporary creative clusters, exhibitions in creative sectors in emerging economies can be viewed as knowledge-intense events that bring about new ideas, inspirations, and further innovation. As for emerging economies, burgeoning international exhibitions can contribute to sustainable economic growth through the effects of knowledge spillover and opportunities inspiring innovation. It has been suggested that creative exhibitions should be encouraged in emerging economies to improve the conditions of interactions among different actors on the site for knowledge transfer and innovation.

The observation that relationships among global buzz, global pipelines, information acquisition, and further innovation are refined in a quantificational way can be considered as another contribution to research on temporary clusters. Global buzz functions as the gathering of various resources and activities, as well as the interactions and observations. Global pipelines act as trans-local linkages, through which specific information may be transmitted and specific relationships are likely to be built or maintained with lower cost. Global buzz and global pipelines promote each other. Both facilitate the acquisition of information and further innovation. In the case of the Beijing Design Week, innovation comes more from global buzz rather than from global pipelines. This case study has also shown that the importance of temporary clusters in information transfer and innovation may also have something to do with the organizational context, namely, the organization of such events. The potential of the global pipelines in temporary clusters could increase if organizers make organizational improvements inspiring knowledge innovation, such as breaking more internal barriers for specific inner activities, recruiting more professional volunteers, and encouraging the presence of core exhibitors.

This case study has also shown the importance of linkages among peers or friends rather than upstream and downstream relationships, as well as the cooperation and interactions with universities or other actors outside the creative industries. It has highlighted the importance of cross-sector interactions in temporary creative clusters. It has shown that various actors and institutions from other fields facilitate the global buzz and global pipelines in the Beijing Design Week, and that they jointly construct it as a cross-sector event. These cross-sector interactions have successfully demonstrated the specific ecology of creative industries in temporary clusters and confirmed Bathelt's opinion that global buzz and global pipelines do not act in the same manner in different exhibitions, industries, and value chains.

Some inadequacies of this research need to be noted, however. Our questionnaire data were only collected during the exhibition, and formal global pipelines established after the event were not covered in this research. This leads to issues needing further investigation. Furthermore, extant research $[12,19]$ has noted that the value of knowledge gained in temporary clusters gets multiplied when it gets inserted into the buzz of a permanent cluster. Meanwhile, more and more exhibitions are being held within permanent clusters. This issue deserves more academic attention, particularly with regard to the (potential) effects of temporary clusters on permanent clusters, in terms of knowledge and innovation diffusion. In addition, the roles of different agencies such as leading companies, organizers, and universities, besides exhibitors and participants deserve further investigation, to make clear the importance of the organizational context in the knowledge innovation of temporary clusters.

Acknowledgments: This research is supported by the National Natural Science Foundation of China (project code: 40701039); Fundamental Research Funds for the Central Universities (project code: 2014KJJCB03); Research Funds for Undergraduates at Beijing Normal University. We would like to thank three anonymous referees for their constructive comments on an earlier version of the paper. We also would like to extend our thanks to all the interviewee in the surveys, and Yang Cheng and Jing Ma at Beijing Normal University for their suggestions on the SEM processing. 
Author Contributions: Huasheng Zhu contributed to the conceptual framework of the paper; Kebi Chen and Yunlong Lian contributed to the fieldwork.

Conflicts of Interest: The authors declare no conflicts of interest.

\section{Appendix A}

Table A1. Occupational areas of interviewees.

\begin{tabular}{llll}
\hline Number & Occupational Area & Number & Occupational Area \\
\hline V1 & Industrial design & V20 & Digital technology \\
V2 & Urban design & V21 & Architecture \\
V3 & Architecture & V22 & Visual conduction design \\
V4 & Architecture & V23 & Environmental art design \\
V5 & Public space design & V24 & Internet design \\
V6 & Advertisement & V25 & Urban design \\
V7 & Industrial design & V26 & New media design \\
V8 & Arts and crafts production and sales & V27 & Software designing \\
V9 & Arts & V28 & Garden design \\
V10 & Marketing of art books & V29 & Architecture \\
V11 & Exhibition & V30 & Filming and TV arts design \\
V12 & Exhibition & V31 & Architecture \\
V13 & Industrial design & V32 & Architecture \\
V14 & Industrial design & V33 & Graphic design \\
V15 & Film director & V34 & Architecture \\
V16 & Graphic design & V35 & Architecture \\
V17 & Industrial design & V36 & Furniture design \\
V18 & User interface, UI & V37 & Urban design \\
V19 & Graphic design & & \\
\hline
\end{tabular}

\section{References}

1. Maskell, P. Accessing remote knowledge-The roles of trade fairs, pipelines, crowdsourcing and listening posts. J. Econ. Geogr. 2014, 14, 883-902. [CrossRef]

2. Bathelt, H.; Henn, S. The Geographies of Knowledge Creation over Distance: Toward a Typology. Environ. Plan. A 2014, 46, 1403-1424. [CrossRef]

3. Jordan, D. The effects of the frequency of spatially proximate and distant interaction on innovation by Irish SMEs. Entrepreneurship Reg. Dev. 2012, 24, 705-727.

4. Asheim, B.T. Temporary Organisations and Spatial Embeddedness of Learning and Knowledge Creation. Geogr. Ann. Ser. B Hum. Geogr. 2002, 84, 111-124. [CrossRef]

5. Martin, R. Roepke Lecture in Economic Geography: Rethinking regional path dependence: Beyond lock-in to evolution. Econ. Geogr. 2010, 86, 1-27. [CrossRef]

6. Hassink, R. Locked in Decline? On the Role of Regional Lock-ins in Old Industrial Areas. In Handbook of Evolutionary Economic Geography; Boschma, R., Martin, R., Eds.; Edward Elgar: Cheltenham, UK, 2010; pp. 450-468.

7. Trippl, M.; Grillitsch, M.; Isaksen, A. Exogenous sources of regional industrial change: Attraction and absorption of non-local knowledge for new path development. Prog. Hum. Geogr. 2017, 1-19. [CrossRef]

8. Bougrain, F.; Haudeville, B. Innovation, Collaboration and SMEs Internal Research Capacities. Res. Policy 2002, 31, 735-747. [CrossRef]

9. Bathelt, H. Buzz-and-Pipeline Dynamics: Towards a Knowledge-Based Multiplier Model of Clusters. Geogr. Compass 2007, 1, 1282-1298. [CrossRef]

10. Gassmann, O.; Gaso, B. Insourcing Creativity with Listening Posts in Decentralized Firms. Creativity Innov. Manag. 2010, 13, 3-14. [CrossRef]

11. Howe, J. Crowdsourcing: Why the Power of the Crowd Is Driving the Future of Business; Crown Business: New York, NY, USA, 2008.

12. Maskell, P.; Bathelt, H.; Malmberg, A. Building global knowledge pipelines: The role of temporary clusters. Eur. Plan. Stud. 2006, 14, 997-1013. [CrossRef] 
13. Bathelt, H. Geographies of production: Growth regimes in spatial perspective (II)—Knowledge creation and growth in clusters. Prog. Hum. Geogr. 2005, 29, 204-216. [CrossRef]

14. Rinallo, D.; Bathelt, H.; Golfetto, F. Economic geography and industrial marketing views on trade shows: Collective marketing and knowledge circulation. Ind. Mark. Manag. 2017, 61, 93-103. [CrossRef]

15. Bathelt, H.; Zeng, G. The development of trade fair ecologies in China: Case studies from Chengdu and Shanghai. Environ. Plan. A 2014, 46, 511-530. [CrossRef]

16. Maskell, P.; Bathelt, H.; Malmberg, A. Temporary Clusters and Knowledge Creation: The Effects of International Trade Fairs, Conventions and Other Professional Gatherings; Space: Toronto, ON, Canada; Heidelberg, Germany, 2004; pp. 1-34.

17. Bathelt, H.; Schuldt, N. International Trade Fairs and Global Buzz, Part I: Ecology of Global Buzz. Eur. Plan. Stud. 2010, 18, 1957-1974. [CrossRef]

18. Power, D.; Jansson, J. Cyclical clusters in global circuits: Overlapping spaces in furniture trade fairs. Econ. Geogr. 2008, 84, 423-448. [CrossRef]

19. Bathelt, H.; Schuldt, N. Between Luminaires and Meat Grinders: International Trade Fairs as Temporary Clusters. Reg. Stud. 2008, 42, 853-868. [CrossRef]

20. El-Mously, H. Innovating green products as a mean to alleviate poverty in Upper Egypt. Ain Shams Eng. J. 2017. [CrossRef]

21. Li, P.F. Temporary clustering in developing economies: Trade fairs in South and Southeast Asia. In Temporary Knowledge Ecologies; Bathelt, H., Zeng, G., Eds.; Edward Elgar Publishing: Cheltenham, UK, 2015; Chapter 5; pp. 93-112.

22. Sun, Y.T.; Cao, C. The evolving relations between government agencies of innovation policymaking in emerging economies: A policy network approach and its application to the Chinese case. Res. Policy 2018, 47, 592-605. [CrossRef]

23. Comunian, R. Temporary Clusters and Communities of Practice in the Creative Economy: Festivals as Temporary Knowledge Networks. Space Cult. 2017, 20, 329-343. [CrossRef]

24. Bathelt, H.; Golfetto, F.; Rinallo, D. Trade Shows in the Globalizing Knowledge Economy; Oxford University Press: Oxford, UK, 2014.

25. Coe, N.M. Global Production Networks in the Creative Industries. In The Oxford Handbook of the Creative and Cultural Industries; Jones, C., Lorenzen, M., Sapsed, J., Eds.; Oxford University Press: Oxford, UK, 2015; pp. 486-501.

26. Yusuf, S.; Nabeshima, K. Creative industries in East Asia. Cities 2005, 22, 109-122. [CrossRef]

27. Pratt, A.C. Policy Transfer and the Field of the Cultural and Creative Industries: What Can Be Learned from Europe? Available online: https:/ /link.springer.com/chapter/10.1007\%2F978-1-4020-9949-6_2 (accessed on 8 March 2018).

28. Kitson, M.; Howells, J.; Braham, R.; Westlake, S. The Connected University Driving Recovery and Growth in the UK Economy; NESTA Research Report; NESTA: London, UK, 2009; pp. 1-45.

29. Li, Y.C. Review: Trade Shows in the Globalizing Knowledge Economy (Bathelt, H.; Golfetto, F.; Rinallo, D. Trade Shows in the Globalizing Knowledge Economy, Oxford University Press, Oxford, UK, 2014). J. Econ. Geogr. 2015, 15, 841-842. [CrossRef]

30. Bathelt, H.; Malmberg, A.; Maskell, P. Clusters and knowledge: Local buzz, global pipelines and the process of knowledge creation. Prog. Hum. Geogr. 2004, 28, 31-56. [CrossRef]

31. Owen-Smith, J.; Powell, W.W. Knowledge Networks as Channels and Conduits: The Effects of Spillovers in the Boston Biotechnology Community. Organ. Sci. 2004, 15, 5-21. [CrossRef]

32. Bahlmann, M.D.; Huysman, M.H.; Elfring, T.; Groenewegen, P. Global Pipelines or Global Buzz? A Micro-Level Approach towards the Knowledge-Based View of Clusters; Serie Research Memoranda; Vrije Universiteit Amsterdam: Amsterdam, The Netherlands, 2009; pp. 1-33.

33. Bauer, T.; Law, R.; Tse, T.; Weber, K. Motivation and satisfaction of mega-business event attendees: The case of ITU Telecom World 2006 in Hong Kong. Int. J. Contemp. Hosp. Manag. 2008, 20, 228-234. [CrossRef]

34. Bathelt, H.; Turi, P.G. Knowledge Creation and the Geographies of Local, Global, and Virtual Buzz. In Knowledge and the Economy; Meusburger, P., Glückler, J., Meskioui, M.E., Eds.; Springer: Dordrecht, The Netherlands, 2013; pp. 61-78.

35. Bathelt, H.; Gibson, R. Learning in 'Organized Anarchies': The Nature of Technological Search Processes at Trade Fairs. Reg. Stud. 2015, 49, 985-1002. [CrossRef] 
36. Østergaard, C.R.; Timmermans, B.; Kristinsson, K. Does a different view create something new? The effect of employee diversity on innovation. Res. Policy 2011, 40, 500-509. [CrossRef]

37. Rodan, S.; Galunic, C. More than Network Structure: How Knowledge Heterogeneity Influences Managerial Performance and Innovativeness. Strateg. Manag. J. 2004, 25, 541-562. [CrossRef]

38. Gertler, M.S. 'Being there': Proximity, organization, and culture in the development and adoption of advanced manufacturing technologies. Econ. Geogr. 1995, 71, 1-26. [CrossRef]

39. Gertler, M.S. Tacit knowledge and the economic geography of context, or the undefinable tacitness of being (there). J. Econ. Geogr. 2003, 3, 75-99. [CrossRef]

40. Rinallo, D.; Golfetto, F. Exploring the Knowledge Strategies of Temporary Cluster Organizers: A Longitudinal Study of the EU Fabric Industry Trade Shows (1986-2006). Econ. Geogr. 2011, 87, 453-476. [CrossRef]

41. Uzzi, B. Social structure and competition in interfirm networks: The paradox of embeddedness. Adm. Sci. Q. 1997, 42, 35-67. [CrossRef]

42. Bathelt, H.; Spigel, B. The spatial economy of North American trade fairs. Can. Geogr. 2012, 56, 18-38. [CrossRef]

43. Ramírezpasillas, M. Resituating Proximity and Knowledge Cross-fertilization in Clusters by Means of International Trade Fairs. Eur. Plan. Stud. 2008, 16, 643-663. [CrossRef]

44. Borgatti, S.P. A Relational View of Information Seeking and Learning in Social Networks. Manag. Sci. 2003, 49, 432-445. [CrossRef]

45. Li, P.F. Global temporary networks of clusters: Structures and dynamics of trade fairs in Asian economies. J. Econ. Geogr. 2014, 14, 995-1021. [CrossRef]

46. Moodysson, J. Principles and Practices of Knowledge Creation: On the Organization of "Buzz" and "Pipelines" in Life Science Communities. Econ. Geogr. 2008, 84, 449-469. [CrossRef]

47. Borghini, S.; Golfetto, F.; Rinallo, D. Ongoing search among industrial buyers. J. Bus. Res. 2006, 59, 1151-1159. [CrossRef]

48. Aarstad, J.; Kvitastein, O.A.; Jakobsen, S.E. Local buzz, global pipelines, or simply too much buzz? A critical study. Geoforum 2016, 75, 129-133. [CrossRef]

49. Fitjar, R.D.; Rodriguez-Pose, A. Networking, context and firm-level innovation: Cooperation through the regional filter in Norway. Geoforum 2015, 63, 25-35. [CrossRef]

50. Hansen, K. Measuring performance at trade shows: Scale development and validation. J. Bus. Res. 2004, 57, 1-13. [CrossRef]

51. Kerin, R.A.; Cron, W.L. Assessing Trade Show Functions and Performance: An Exploratory Study. J. Mark. 1987, 51, 87-94. [CrossRef]

52. Asheim, B.T. Interactive learning and localised knowledge in globalising learning economies. GeoJournal 1999, 49, 345-352. [CrossRef]

53. Zhan, Q. A Model for Knowledge Innovation in Online Learning Community. In Edutainment 2008: Technologies for E-Learning and Digital Entertainment; Springer: Berlin/Heidelberg, Germany, 2008; Volume 5093, pp. 21-31.

54. Dosi, G. The Nature of the Innovative Process. In Technical Change and Economic Theory; Dosi, G., Freeman, C., Nelson, R.R., Silverberg, G., Soete, L.L.G., Eds.; Pinter Publisher: London, UK, 1988; pp. 221-238.

55. Broad Design, New Silk Road. Available online: http://home.163.com/15/0926/00/B4D8UMH900104MRF. html (accessed on 26 September 2015).

56. Beijing Gehua Cultural Development Group. Available online: http://www.gehua.com/html/jtgk/jtj/ (accessed on 26 January 2018).

57. Beijing Design Week (2017). Available online: https:/ / baijiahao.baidu.com/s?id=1575867210097143\&wfr= spider\&for $=p c$ (accessed on 10 January 2018).

58. Beijing Design Week (2017) Ended in Beijing. Available online: http://www.gehua.com/html/2017/jtdt 1009/419.html (accessed on 10 January 2018).

59. Introduction of Three Platforms in Beijing Design Week (2015). Available online: http://home.163.com/15/ 0920/09/B3URHCJV00104MRF.html (accessed on 10 January 2018).

60. Beijing Design Week (2014). Available online: http://home.focus.cn/zhuanti14/2014sjz/,2015-12-20 (accessed on 10 January 2018).

61. Creative Industries Mapping Document. Available online: https:/ /www.gov.uk/government/publications / creative-industries-mapping-documents-1998 (accessed on 12 November 2017). 
62. Florida, R. Cities and the Creative Class. City Community 2003, 2, 3-19. [CrossRef]

63. Andreae, M.; Hsu, J.Y.; Norcliffe, G. Performing the trade show: The case of the Taipei International Cycle Show. Geoforum 2013, 49, 193-201. [CrossRef]

64. Moustaki, I.; Joreskog, K.G.; Mavridis, D. Factor models for ordinal variables with covariance effects on the manifest and latent variables: A Comparison of LISREL and IRT Approaches. Struct. Equ. Model. 2004, 11, 487-513. [CrossRef]

65. Boomsma, A. The robustness of maximum likelihood estimation in structural equation model. In Structural Modeling by Example; Cutance, P., Ecob, R., Eds.; Cambridge University Press: New York, NY, USA, 1987; p. 4.

66. Moutinho, R.; Au-Yong-Oliveira, M.; Coelho, A.; Manso, J.P. Determinants of knowledge-based entrepreneurship: An exploratory approach. Int. Entrepreneurship Manag. J. 2016, 12, 171-197. [CrossRef]

67. Garver, M.S.; Mentzer, J.T. Logistics research methods: Employing structural equation modeling to test for construct validity. J. Bus. Logist. 1999, 20, 33-57.

68. Baumgartner, H.; Homburg, C. Applications of structural equation modeling in marketing and consumer research: A review. Int. J. Res. Mark. 1996, 13, 139-161. [CrossRef]

(c) 2018 by the authors. Licensee MDPI, Basel, Switzerland. This article is an open access article distributed under the terms and conditions of the Creative Commons Attribution (CC BY) license (http:/ / creativecommons.org/licenses/by/4.0/). 